\title{
Water Resources Accounting and Nigeria's Economic Advancement
}

\author{
Cordelia Onyinyechi Omodero ${ }^{1}$,Amah Kalu Ogbonnaya ${ }^{2}$,Azubike, Joseph Uche Belonwu ${ }^{3}$ \\ 1,2,\&3 Michael Okpara University of Agriculture Umudike, Umuahia, Abia State \\ Correspondence: Cordelia Onyinyech Omodero, Michael Okpara University of Agriculture Umudike, Umuahia, Abia State.
}

Received: September 12, 2018

Accepted: September 25, 2018

Available online: February 20, 2019

doi:10.11114/afa.v5i1.4084

URL: https://doi.org/10.11114/afa.v5i1.4084

\begin{abstract}
Water resources accounting is presently a universal challenge due to the high rate of water contamination and other discharges that put nations at risk of water scarcity if precautionary measures are not taken on time. All needed government interventions to reduce the risk of water scarcity is dependent on the extent of water resource accountability available in the country. This paper examines the contribution of water resources accounting to Nigeria's economic advancement. The data employed span from 1981-2017 and have been collected from the CBN Statistical Bulletin, 2017 edition. Ordinary Least Squares technique is used to analyze the date and the result indicates that water resources accounted for, have strong and significant positive impact on the RGDP. The findings also reveal that water resources are estimated to contribute a total of 72.6\% variation in the RGDP between the periods from 1981 to 2017 in Nigeria. Therefore, the study recommends sufficient training and empowerment for all agencies responsible for data gathering of water resources. This will enhance quality water resources' accountability. Policy makers should encourage all forms of water resources accountability and management to sustain the economy by liaising with international bodies and getting updates on global best practices in this area.
\end{abstract}

Keywords: water resources, accounting, management, economic advancement, Nigeria

JEL Classifications: Q 1, Q 25, Q 28

\section{Introduction}

Water is an essential natural resource required to sustain all forms of plant and animal life (Ahmad, Tower, Plummer, \& Aripin, 2010). Water plays a substantial role in all aspects of human life and economic life of a nation (Winpenny, 2012). Sequel to the speedy increase in human population and unstable weather conditions associated with global climate changes, demand for freshwater is growing while at the same time supply is becoming less dependable (Daniel \& Sojamo 2012). Global water resources are coming under increasing pressure due to persistent pollutions and emissions that reduce the usefulness. It is generally predicted that over the next few decades, global drivers such as climate change, population growth and improving living standards will intensify pressure on the availability and supply of quality water resources (Winpenny, 2012). Estimates by World Water Development Report (WWDR, 2016) suggests that by 2050, if the management and usage of water continue in the present manner it is, global water demand will surpass supply by over $40 \%$ which would put at risk $45 \%$ of global GDP, $52 \%$ of the world's population, and $40 \%$ of grain production. Therefore, it is never by accident that the World Economic Forum (WEF) has steadily grades water crises as the highest global risk (WEF, 2015).

To support this fact, Australia wine industry is most vulnerable to water-related pressures and risks as water is very important for wine grape cultivation and wine production (Katherine, 2015). Studies have shown that access to water access and its management have been a huge concern for managers of the wine industry in Australia (Alonso, 2010; Mosse, Patti, Christen, Cavagnaro, 2011). The fact is that, the quality of water for usage is very important and therefore its pollution limits the activities it is used for and, in some cases, renders it unfit for future use both in the short and long run (Gleick 1998). These circumstances have led to growing emphasis being placed on responsible use of water (Goesch, Hone \& Gooday 2007; Herberger 2012).

Due to lack of proper accounting for water, economic policy-makers are beginning to express worry considering the significance of water for national economies (Winpenny, 2012). The problem has been that water management decisions rely on rough estimates that are statistically erroneous, misleading and ecologically detrimental (Mosse, et al., 2011). It has been foreseen that if companies are not properly directed to use water in an efficient and effective manner, there could 
be possible environmental hazards to contend with (Herberger, 2012). These issues have led to growing interest in water accounting in parallel with broader environmental accounting. The United Nations (UN) System of EnvironmentalEconomic Accounts for Water (SEEAW) and Eurostat, Organization for Economic Co-operation and Development (OECD) and recently the European Environment Agency (EEA) are agencies that have made efforts and come up with the initiative of incorporating water-related indicators into wider systems of environmental accounting as a way of enhancing water accountability and highlighting its role in economic and environmental policy making (Winpenny, 2015).

Keeping in line with the global trend, India is developing a blueprint for national water accounting (Schmidt, Bassi, \& Benitez Sanz, 2017). In 2013, Asian Development Bank (ADB) published a policy paper titled "Thinking about Water differently", in order to promote water accounting which will help to evaluate water supply and demand management policies (ADB, 2013). Following the long history of water accounting in the Murray-Darling Basin, the Australian Bureau of Meteorology (BOM) decided to host the Australian Water Accounting Standard (BOM, 2017). The Public Policy Institute of California (PPIC) made a recommendation that water accounting be adopted to manage water before and after the existing drought (PPIC, 2016). In Nigeria, the Ministry of Water Resources takes the responsibility of water resources exploration and utilization. Water resources represent an important parameter of the environment on which the nation depends for agriculture and industrial purposes. Water resources have basic socio-economic importance especially in the area of fishing, domestic water supply and hydroelectric power (HEP) generation in Nigeria (The Analyst, 2018).

The National Water Resources Institute (NWRI) is a major source of data on water resources in Nigeria. It is a department under the Ministry of Water Resources. Their data bank collects, stores and retrieves hydro meteorological data for planning purposes. Statistics on water resources and rural development include time-series observation on the activities and outputs of the rural development programmes, the hydrological stations and the river basin development authorities. The data captured on water resources include: 1 . Hydrology - surface water discharge and storage; 2. Meteorology rainfall, evaporation humidity, temperature wind speed; 3. Hydrogeology - underground water systems etc. (The Analyst, 2018). The Nigerian Meteorological Agency (NMA) provides data on monthly rainfall in millimeters (CBN, 2017). Therefore, the purpose of this study is to determine the contribution of water resources accounting to sustainable development in Nigeria.

\subsection{Hypothesis}

$\mathrm{Ho}_{1}$ : Water resources accounting (WTRS) does not have significant influence on the real gross domestic product (RGDP) in Nigeria.

\section{Literature Review}

\subsection{Conceptual Review}

\subsubsection{Water Resources and Danger of Contamination}

Water is an essential substance upon which all life depends. Where there is water there is life, and where there is scarcity of water, life becomes a struggle (UNESCO, 2011). Scarcity of safe drinking water could be as a result of contamination caused by geogenic arsenic (Inauen, 2012). Geogenic arsenic in groundwater affects almost 100 million people globally (Ahmed et al., 2006). Bangladesh is the most affected nation, with at least 20 million people at risk of drinking water

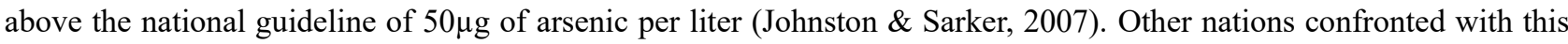
menace include the USA (Shaw, Walker, \& Benson, 2005), Argentina (Bundschuh et al., 2004), Cambodia (Buschmann, Berg, Stengel, \& Sampson, 2007) and many others (Amini, Abbaspour et al., 2008). Arsenic is a metalloid which naturally exists in the surroundings (Hughes, Beck, Chen, Lewis, \& Thomas, 2011). It is extremely toxic and is regarded as a carcinogen (Hughes et al., 2011). Through complex chemical processes, arsenic is seeped from aquifer rocks and sediments and stores in groundwater (Smedley \& Kinniburgh, 2002). To make arsenic discovery difficult, its distribution in a certain region is not evenly; if a particular household has an arsenic contaminated well, the neighbour's well may be arsenic safe and vice versa (Inauen, 2012).

There are various health problems associated with too much arsenic consumption. Arsenic intake may cause arsenicosis, which leads to skin alterations, cancers of the skin, bladder, and lung ((Ahsan et al., 2006; Chen \& Ahsan, 2004). The incidence of arsenicosis is difficult to evaluate. In West Bengal, 300'000 skin lesions due to arsenic exposure were reported and there were likely to be more in neighboring Bangladesh (Chakraborti et al., 2004). Further associated diseases are peripheral vascular diseases (e.g. blackfoot disease), cardiovascular diseases (Chen et al. 2007), and impaired neurodevelopment in children (Wasserman et al., 2004).

\subsubsection{Water Accounting and Sustainable Development}

Rising world population and urbanization, coupled with a growing demand for food and the need to secure environmental flows have led to increased demand for water (Amarasinghe \& Smakhtin, 2014; FAO, 2012; Green et al. 2015). Following the growing populations with better goals for affluence, national and local governments and organizations are more 
worried with sustainable growth that does not erode fundamental ecosystems (UN, 2017). The implication is that, strategies for economic development require verification on demand for water and their influence on present arrangements of water distribution. Water scarcity is the excess of water demand over supply and is largely driven by human, economic, and societal factors. Water shortage is a natural phenomenon witnessed during droughts (World Water Council (WWC), 2018).

The level of attention given to household and business accounting is not similar to water accounting. Water is precious and limited in supply. This is why water resource is recognized as a major issue in the implementation of UN 2030 Agenda for sustainable development (WWC, 2018). Therefore, accounting for water can be considered as an avenue or a mechanism through which water users can discharge accountability (Russel \& Lewis, 2014).

Water accounting is the systematic quantitative assessment of the status and trends in water supply, demand, distribution, accessibility and use in specified domains, producing information that informs water science, management and governance to support sustainable development outcomes for society and the environment (FAO, 2012, 2016). According to WWC (2018), water accounting is about understanding the hydro-logical cycle, measuring longitudinal and cyclical disparities in rainfall with volatile excesses of floods and droughts. It takes cognizance of medium and long-term variations in demand across all water users - communities, farming, energy, industry, and the environment - and inform water infrastructure investment such as pumping, storage, and planning for climate change (WWC, 2018).

From the various definitions, water can be referred to as an essential resource required to sustain life of humans, animals and plants while it uses are essential for the survival of companies engaged in the production of food, wine and beverages. Water accounting is therefore the collection of all water related data for better distribution and management of water resources.

Water accounting is employed to update policy makers as to whether interventions (such as new dams, irrigation schemes or water law reform) will substantially contribute to the management of water scarcity and competition (WWC, 2018). Economic planners and environmental organizations need water accounting to examine whether their plans could lead to sufficient supply of water to all users and for all uses.

\subsubsection{Water Accounting Disclosure and Report}

Water accounting is used to describe the activities of disclosure as the act of collecting and making available data on the current state of water management (Morrison \& Schulte, 2012). Water management concerns the active management of water on a daily, weekly, seasonal and annual basis using combined operations involving people, infrastructure, finance, and other inputs and resources (WWC, 2018). Therefore, water accounting reports must be general purpose reports and useful to the users. Statement of Water Accounting Concept (SWAC 3) provides the following qualities: relevance, faithful representation, comparability, verifiability, timeliness and understandability (Water Accounting Standards Board (WASB, 2009). SWAC 4 provides for water assets and liabilities. Water assets include the legal right to control water asset e.g. lakes, and the future benefits. The liabilities include all enforceable obligations. For instance, water deliverable under contract or an allocation under water sharing plan (WASB, 2009).

2.1.4 Potential Water Resource Accounting System as Identified by (Flemming, Berit, Marianne, Louise, \& Pedersen, 2015)

The potential water resource accounting system includes four different types of accounts:

- Water amount accounts. This is the account of fresh water flows and storage (inventory) measured in $\mathrm{M}^{3}$.

- Emission to water accounts. This is the account of different pollutants emitted to fresh water by industries and households measured in $\mathrm{Kg}$ or litre.

- Water quality accounts. This is where quality of different fresh water resources is stated in relevant natural units of measurement. For instance, concentrations of different pollutants or ordinal measures such as good, medium and bad quality.

- Ecosystem services account where the amount and value of different ecosystem services supplied by different freshwater areas are stated.

\subsubsection{Water Inventory Accounting Inventory Accounting}

Water Inventory Accounting comprises opening and closing inventory (including increases and decreases during the year) of ground and surface water resources. The quantity of water is increased by natural processes - primarily precipitation/rainfall - and human activities among which discharge of waste water is the most important, but also building of new draining facilities. The water storage is decreased by evaporation and outflow to the sea or ecological water consumption of rivers and lakes which are natural processes and by water intake which are human activities. The account does not include water in soil, seawater and water in the atmosphere (Flemming et al., 2015; Yang, Yang, Cao, \& Cheng, 2017). 
Table 2.1 Format for water inventory accounting

\begin{tabular}{|c|c|c|c|}
\hline & Ground Water & Surface Water & Total \\
\hline & $\begin{array}{c}\text { Million } \\
\mathrm{M}^{3}\end{array}$ & $\begin{array}{c}\text { Million } \\
\mathrm{M}^{3}\end{array}$ & $\begin{array}{c}\text { Million } \\
\mathrm{M}^{3}\end{array}$ \\
\hline OPENING INVENTORY & $\mathrm{X}$ & $\mathrm{X}$ & $\mathrm{XX}$ \\
\hline \multicolumn{4}{|l|}{ Add Increase from natural processes: } \\
\hline - $\quad$ Precipitation & $\mathrm{X}$ & $\mathrm{X}$ & $\mathrm{XX}$ \\
\hline - $\quad$ Other Inflows & $\mathrm{X}$ & $\mathrm{X}$ & $\mathrm{XX}$ \\
\hline \multicolumn{4}{|l|}{ Add Increase from human activities: } \\
\hline - Waste Water & $\mathrm{X}$ & $\mathrm{X}$ & $\mathrm{XX}$ \\
\hline - $\quad$ Draining & $\mathrm{X}$ & $\mathrm{X}$ & $\mathrm{XX}$ \\
\hline TOTAL BROUGHT-IN WATER RESOURCES & $\mathrm{X}$ & $\mathrm{X}$ & $\mathrm{XX}$ \\
\hline \multicolumn{4}{|l|}{ Less Decrease from natural processes: } \\
\hline - $\quad$ Evaporation & $\mathrm{X}$ & $\mathrm{X}$ & $\mathrm{X}$ \\
\hline - $\quad$ Outflow to Seas and Lakes & $\mathrm{X}$ & $\mathrm{X}$ & $\mathrm{X}$ \\
\hline - $\quad$ Other Outflows & $\mathrm{X}$ & $\mathrm{X}$ & $\mathrm{X}$ \\
\hline Less decrease from human activities: & $\mathrm{X}$ & $\mathrm{X}$ & $\mathrm{X}$ \\
\hline - Water Intake & $\mathrm{X}$ & $\mathrm{X}$ & $\mathrm{X}$ \\
\hline CLOSING INVENTORY & $\mathrm{X}$ & $\mathrm{X}$ & $\mathrm{X}$ \\
\hline
\end{tabular}

Source: Flemming et al., (2015); Yang et al., (2017).

\subsubsection{Emission Account for one Type of Pollutant}

Contaminants or pollutants confined in rain water which run straight into freshwater and sea or flow to the sewage industries, freshwater or sea through sewers are included in the emission accounts. Also pollutants which are conveyed into national water by streams from overseas nations are incorporated. The accounts only comprise toxins contained in water that is emitted to water and therefore, atmospheric sediments directly to water are not included in the accounts (Flemming, et al., 2015).

Table 2.2 Format for emmission account for one type of pollutant

\begin{tabular}{lcccccc}
\hline & Industries & $\begin{array}{c}\text { Sewage } \\
\text { Industry }\end{array}$ & $\begin{array}{c}\text { House- } \\
\text { holds }\end{array}$ & Rain & $\begin{array}{c}\text { Foreign } \\
\text { Countries }\end{array}$ & Total \\
\hline Without treatment to Fresh water & $\mathrm{X}$ & $\mathrm{X}$ & $\mathrm{X}$ & $\mathrm{X}$ & $\mathrm{X}$ \\
\hline Without treatment to Sea & $\mathrm{X}$ & $\mathrm{X}$ & $\mathrm{X}$ & $\mathrm{X}$ & $\mathrm{X}$ & $\mathrm{XX}$ \\
\hline After treatment to Fresh water & $\mathrm{X}$ & $\mathrm{X}$ & $\mathrm{X}$ & $\mathrm{X}$ & $\mathrm{X}$ & $\mathrm{XX}$ \\
\hline After treatment to Sea & $\mathrm{X}$ & $\mathrm{X}$ & $\mathrm{X}$ & $\mathrm{X}$ & $\mathrm{X}$ & $\mathrm{XX}$ \\
\hline Direct Emissions to water (A) & $\mathrm{X}$ & $\mathrm{X}$ & $\mathrm{X}$ & $\mathrm{X}$ & $\mathrm{X}$ & $\mathrm{XX}$ \\
\hline To Waste water treatment industry (B) & $\mathrm{X}$ & & $\mathrm{X}$ & $\mathrm{X}$ & & $\mathrm{XX}$ \\
\hline Actual Emissions by source (A+B) & $\mathrm{X}$ & $\mathrm{X}$ & $\mathrm{X}$ & $\mathrm{X}$ & $\mathrm{X}$ \\
\hline Reallocations of gross emissions from sewage & $\mathrm{X}$ & $(\mathrm{X})$ & $\mathrm{X}$ & $\mathrm{X}$ & $\mathrm{X}$ \\
industry & & $\mathrm{X}$ & & $\mathrm{X}$ & $\mathrm{X}$ & $\mathrm{X}$ \\
\hline NET EMISSIONS (A+D) & $\mathrm{X}$ & & $\mathrm{X}$ & $\mathrm{X}$ & $\mathrm{X}$ \\
\hline Emission removed by sewage industry (B-D) & & & $\mathrm{X}$ \\
\hline Source: & & & & \\
\hline
\end{tabular}

Source: Flemming et al., (2015)

\subsection{Theoretical Review}

The theories underpinning this study are the protection motivation theory and contingency theory. 


\subsubsection{Protection Motivation Theory}

Rogers $(1975,1983)$ became the major proponent of this theory. The theory has threat appraisal and coping appraisal. Threat appraisal places emphasis on the maladaptive response of man especially when faced with no options. Though he is aware of the arsenic contamination of the water at present, he tries to adapt to drinking and using it as against his wish. The coping appraisal focuses on his adaptive response which is caused by the social influence on him. He believes that the threat of the toxic water can be overlooked since there is a wide range of social approval to the intake of the water available, despite the health challenges it can cause. This theory confirms the reason why water accounting should be taken seriously. Water accounting helps the government to take into consideration the extent and amount of safe drinking water available for the citizens in every region of a country at every given time. It provides an avenue to determine the level of hazards following contamination and pollution of water in the surroundings of a community or town. This helps for quick government intervention where necessary since human beings cannot stay without water, they accept whatever water that is available to them whether safe or toxic.

\subsubsection{Contingency Theory}

The risk associated with scarcity of water resource globally gives credence to the use of this theory in this study. Contingency theory posits that organizations are permitted to structure their activities (including accounting system) in such a manner that could best suit the situation they find themselves at every point in time (Chenhall, 2003, Malmi \& Granlund, 2009; Otley 1980). The most important thing is the achievement of corporate goals and enhancement of organizational performance (Chenhall, 2003). Therefore, contingency theory will help organizations to adjust their accounting structure in a manner that water accounting can be incorporated to enhance its management. The practice will help to achieve national economic goals and sustainability.

\subsection{Empirical Review}

Yang et al. (2017) assessed the method of evaluating water resource assets and liabilities using Jinan City in Shandong Province of China as the case study. The study tried to proffer solution to the severe water crisis caused by policy issues in China. The study identified water resource assets and calculated them from 2011-2015. To create the balance sheet, the study used unit price of water, water quantity and quality, physical and quantitative accounting methods. The calculation revealed that water resource assets increased and decreased in Jinan City within the period. In 2011, 2012, 2013, 2014 and 2015, water resource assets totaled $\$ 36.5 \mathrm{~m}, \$ 45.9 \mathrm{~m}, \$ 66.7 \mathrm{~m}, \$ 35.5 \mathrm{~m}$ and $\$ 37.5 \mathrm{~m}$ respectively. The study therefore, provided quantitative and physical evidence for proper management and accountability of water resources.

Katherine (2015) studied environmental management accounting as a medium for improved water management in the Australian wine industry. The vulnerability of wine industry to water-related pressures and risks was on the high side. The study made use of questionnaire-survey in which managers in wine producing organizations in Australia were the respondents. The multiple regression analysis revealed that water-related environmental management accounting (EMA) used by wine organizations differ due to the contingent and institutional influences. However, the study provided empirical evidence that the use of water-related EMA in the wine industry resulted to improved water management in Autralia.

Egan (2012) investigated water management and accounting in food and beverage producing organizations in Australia. The study employed primary source of data to evaluate the effectiveness of water management and accounting in organizations. The organizations used for the study were about seven in number. Pervasive water management and accounting was practiced by two organizations. In those two organizations, water management and accounting became the responsibility of all staff. The usage was regularly regulated and scrutinized while reports to executives were steadily submitted. The other five organizations also studied demonstrated little initiative of the whole idea of water accounting. The study concludes that water accounting and management need to be institutionalized. The practice should be embraced by all organizations for a better and efficient use of water resources.

Tisdell (2001) examined the consequences of introducing trade and allocating water for environmental use in the Border Rivers region of Queensland. Water markets were developing as part of the initiative of the Council of Australian Governments to promote an efficient use of water resources in Australia. The result of the study however revealed that water trading could reduce the natural flow systems and increase extractive water-use which is profit oriented and could render water policies in Australia ineffective.

\subsection{Gap in Literature}

Many scholars have carried out studies on water resource accounting and management in different ways. Few of the studies are empirical while majority are theory based. In the course of this research, the major constraint was the lack of adequate empirical studies to compare the findings of this work with. However, this study is filling this gap as one empirical study in water accounting carried out in Nigeria and focused on the sustainability of the economy. 


\section{Methodology}

Water resource accounting data are usually ex-post facto as a result they are historical and are reported annually in Nigeria. Therefore, the study adopted ex-post facto research design because there is no room for data manipulation as the data are already in existence. The data were collected from the Central Bank of Nigeria Statistical Bulletin, 2017 on water resources and real gross domestic product. The data covered a period from 1981-2018. The study made use of simple linear regression since the explanatory variable (water resource) is one. The method of data analysis is the Ordinary Least Square (OLS) technique. The statistical formulation of the model are presented as follows:

RGDP $=\mathrm{f}(\mathrm{WTRS})$

The simple linear relationship is stated thus:

LOGRGDP $=\beta_{0}+\beta_{1}$ LOGWTRS $+\mu$

Where:

RGDP - Real gross domestic product

WTRS - Water resources

$\beta$ - Intercept

$\beta$ - Estimation Coefficient

$\mu$ - Error term

\section{Data Analysis and Interpretations}

\section{LOGWTRS}

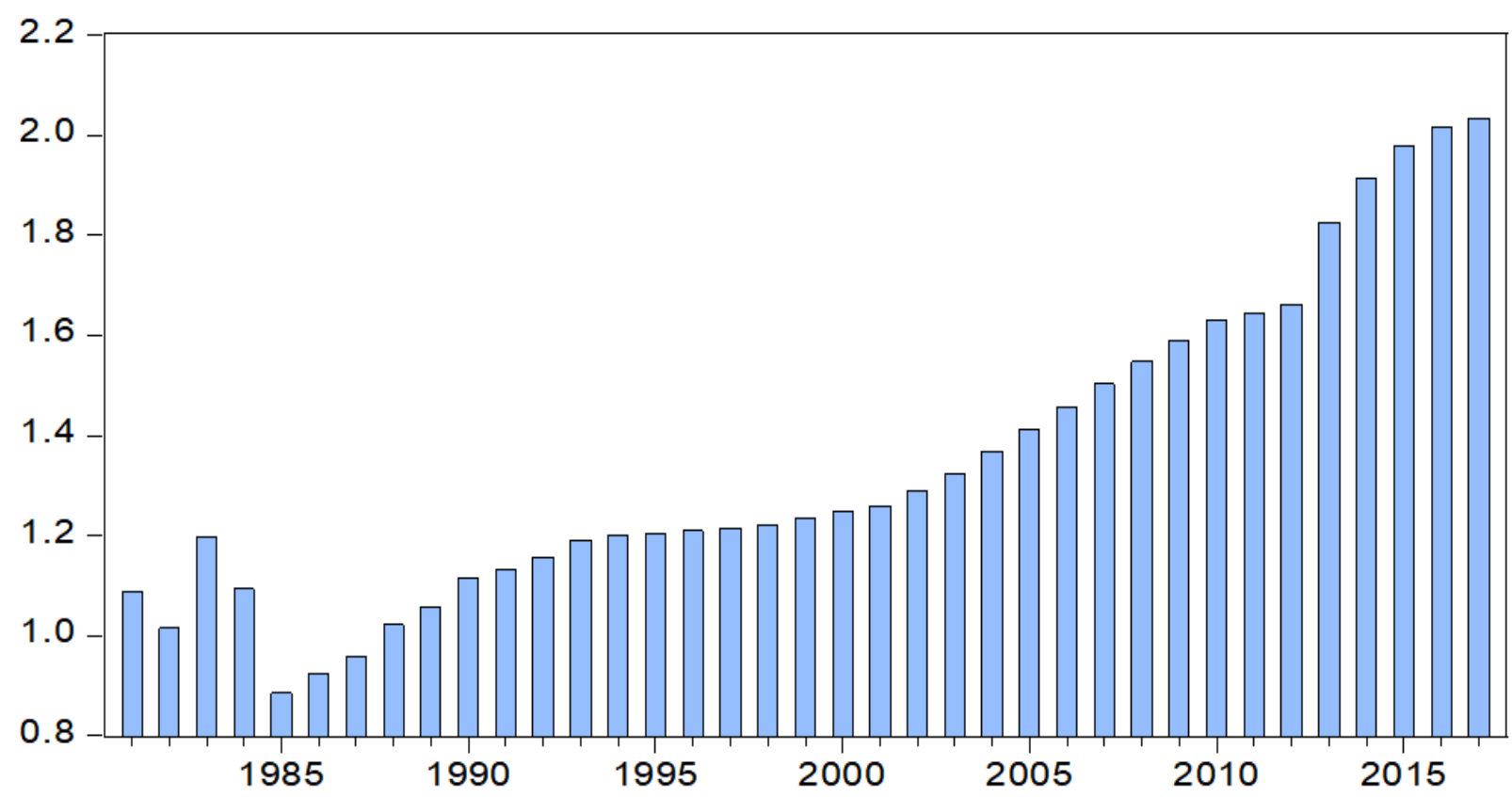

Figure 4.1 Data trend of water resources in Nigeria from 1981-2017

Source of data: CBN Statistical Bulletin, 2017

Figure 4.1 represents the trend of water resources contribution to real gross domestic accounted for from 1981-2017. The trend shows that in 1985 the activity of water supply, sewage and waste management was at the lowest level while the trend kept rising until it got to its peak at 2017. This implies that the water resource accounting and management for economic sustainability are gaining ground in Nigeria and the awareness is increasing in a manner that data capturing of the water resources is becoming more efficient and effective. 


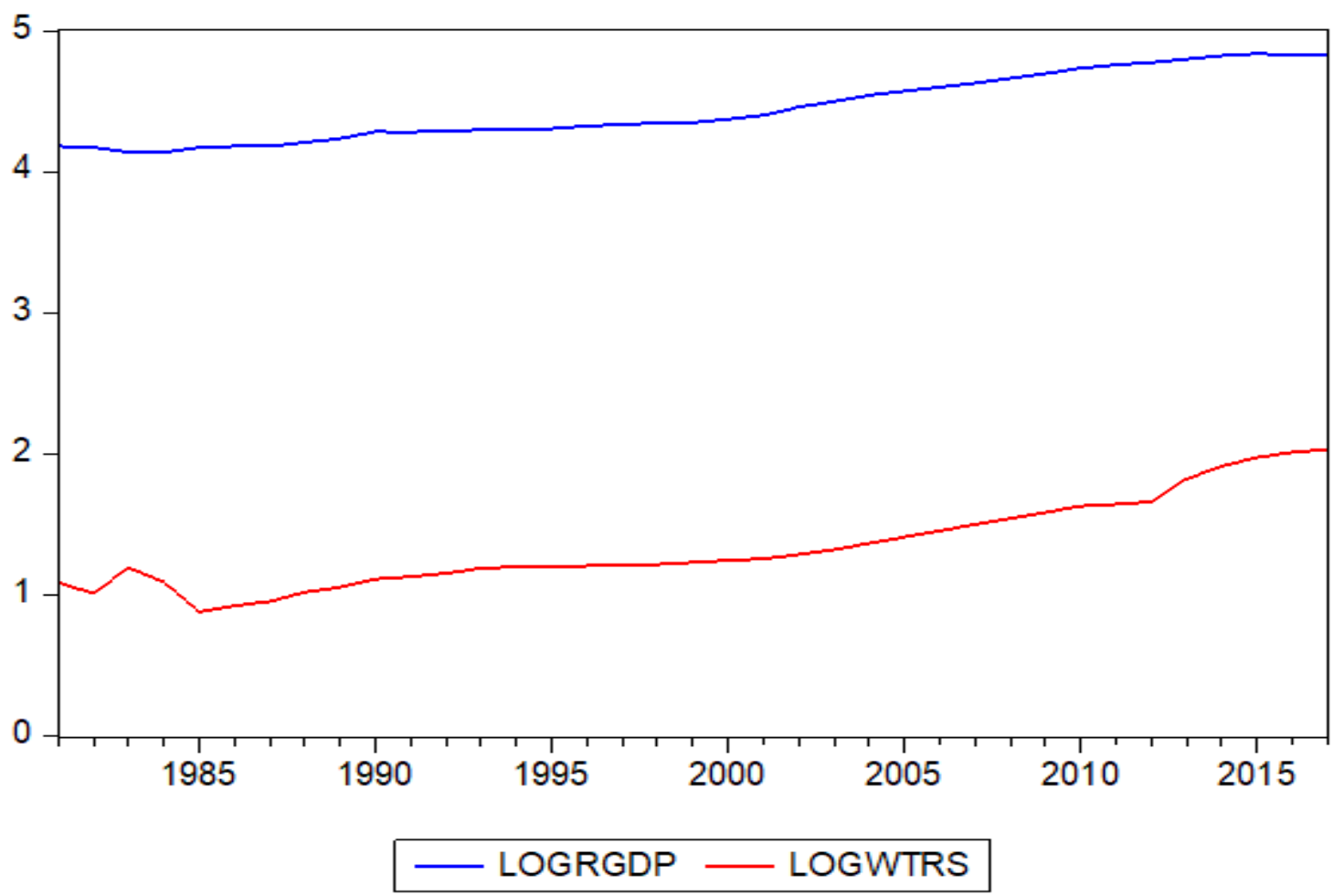

Figure 4.2 Trend of RGDP and WTRS from 1981-2017

Source of Data: CBN, Statistical Bulletin, 2017

Figure 4.2 depicts the extent to which WTRS could contribute to the RGDP. However, due to the increasing global awareness of the importance of water resource accountability, there is great improvement in the trend. The implication is that more improvement in the data management is possible and will enhance economic sustainability following the initiative and recommendations of the international bodies (UN, OECD, EEA, PPIC etc.) in the adoption of proper accounting and management of water resources.

Table 4.1 Summary table of ADF unit root test and order of integration

\begin{tabular}{lccccc}
\hline Variable & ADF T-statistics & $\begin{array}{l}\text { Mackinnon } \\
\text { critical value at } \\
5 \%\end{array}$ & P-Value & $\begin{array}{l}\text { Order of } \\
\text { Integration }\end{array}$ & Remarks \\
\hline RGDP & -3.339751 & -2.948404 & 0.0205 & $\mathrm{I}(1)$ & Stationary \\
\hline WTRS & -5.672721 & -2.948404 & 0.0000 & $\mathrm{I}(1)$ & Stationary \\
\hline
\end{tabular}

Source: Authors' Computation, 2018

Table 4.1 above is the unit root test of the data set to establish stationarity of the data. This is to avoid misleading regression result from the Ordinary Least Square technique used for the analysis. From the table 4.1 the data sets are stationary at first difference.

Table 4.2 Johansen cointegration test

\begin{tabular}{|c|c|c|c|c|}
\hline \multicolumn{5}{|c|}{ Date: $08 / 31 / 18$ Time: $13: 24$} \\
\hline \multicolumn{5}{|c|}{ Sample (adjusted): 19832017} \\
\hline \multicolumn{5}{|c|}{ Included observations: 35 after adjustments } \\
\hline \multicolumn{5}{|c|}{ Trend assumption: Linear deterministic trend } \\
\hline \multicolumn{5}{|c|}{ Series: LOGRGDP LOGWTRS } \\
\hline \multicolumn{5}{|c|}{ Lags interval (in first differences): 1 to 1} \\
\hline \multicolumn{5}{|c|}{ Unrestricted Cointegration Rank Test (Trace) } \\
\hline Hypothesized & & Trace & 0.05 & \\
\hline No. of CE(s) & Eigenvalue & Statistic & Critical Value & Prob.** \\
\hline None * & 0.382941 & 17.17688 & 15.49471 & 0.0277 \\
\hline At most 1 & 0.007946 & 0.279226 & 3.841466 & 0.5972 \\
\hline \multicolumn{5}{|c|}{ Trace test indicates 1 cointegrating eqn(s) at the 0.05 level } \\
\hline \multirow{2}{*}{\multicolumn{5}{|c|}{$\begin{array}{l}* \text { denotes rejection of the hypothesis at the } 0.05 \text { level } \\
* * \text { MacKinnon-Haug-Michelis }(1999) \mathrm{n} \text {-values }\end{array}$}} \\
\hline & ichelis (1999 & & & \\
\hline
\end{tabular}

Source: Authors' Computation, 2018 
The table 4.2 above reveals a short run co-integration between the dependent and the independent variable, hence the choice of the Ordinary Least Squares technique for the analysis.

Table 4.3 Regression result

\begin{tabular}{|c|c|c|c|}
\hline Dependent Variable: LOGRGDP & & & \\
\hline Method: Least Squares & & & \\
\hline Date: $08 / 31 / 18 \quad$ Time: $13: 28$ & & & \\
\hline Sample: 19812017 & & & \\
\hline Included observations: 37 & & & \\
\hline Variable & Coefficient & t-Statistic & Prob. \\
\hline LOGWTRS & 0.725852 & 19.75311 & 0.0000 \\
\hline $\mathrm{C}$ & 3.472137 & 68.39026 & 0.0000 \\
\hline R-squared & 0.917683 & Mean dependent var & 4.449360 \\
\hline Adjusted R-squared & 0.915331 & S.D. dependent var & 0.238413 \\
\hline S.E. of regression & 0.069373 & Akaike info criterion & -2.446094 \\
\hline Sum squared resid & 0.168442 & Schwarz criterion & -2.359017 \\
\hline Log likelihood & 47.25274 & Hannan-Quinn criter. & -2.415395 \\
\hline F-statistic & 390.1853 & Durbin-Watson stat & 0.519069 \\
\hline Prob(F-statistic) & 0.000000 & & \\
\hline
\end{tabular}

Source: Authors' Computation, 2018

From table 4.3 above, the correlation (R) value is $95.8 \%$ (Square root of $\mathrm{R}^{2}$ ), this connotes a very strong relationship between WTRS and RGDP. The R-Squared of $91.8 \%$ is equally very substantial. The implication is that WTRS explains about $91.8 \%$ variations in the RGDP while only $8.2 \%$ of the changes could be associated with other factors not considered in the model. The F-statistics is 390.1853 and has a p-value of $0.000<0.05$. The result is statistically significant and shows that the model is appropriate for the study. The Durbin-Watson is approximately 1 and does not really give cause for concern.

The study earlier hypothesized that WTRS does not have significant impact on the RGDP. From the regression result on table 4.3, the t-statistics is 19.75311 with a p-value of $0.000<0.05$. Therefore, the null hypothesis is rejected and the alternative accepted.

Discussion on findings:

The result of this study has provided an empirical evidence that water resources can contribute to sustainable development in Nigeria. Therefore, private and government organizations have the responsibility to maintain water resource accountability and management. In Nigeria, water resources data comprises, water supply, sewage and waste management. It is necessary for water accounting to incorporate water inventory accounting and emission account. Inventory accounting takes care of groundwater and surface water storage in million millimeters. The improvement in the water resource accounting can help to have a check on water supply effectiveness. Nigeria is such a place that safe drinking water is difficult to come by due to environmental pollutions and emissions especially in the Niger Delta region. The Northern region has a lot of rocks, as such water resource in those areas could be exposed to arsenic that leaches from aquifer rocks and sediments and accumulates in groundwater. Water resource accounting provides information on these issues and will help the country to have a healthy drinking water and safe environment if the government takes the necessary measures.

\section{Conclusion and Recommendation}

Following the regression result of this study, it can be concluded that water resources accounting contributes immensely to sustainable economic development. Therefore, the study suggests that the global trend of water resource accounting should be adopted in the country to avoid exposure to water-related hazards. Water resources accounting provides information on quantity and availability of safe drinking water and the dangers of emissions and pollutants that destroy our water. Therefore, the agencies (such as the Nigeria Meteorological Agency (NMA)) that specialize in the capturing of relevant water resources data (monthly rainfall) should be encouraged. The Ministry of Water Resources, 12 River Basin Development Authorities (RBDAs) and the National Water Resources Institute in the country should be empowered to give the best of their service. Water resource accounting in Nigeria deserves maximum recognition and practice in Nigeria. Therefore, policy makers should support the existing agencies and endeavor to establish more institutions that 
will have the capacity to engage in water accountability and organize trainings for companies and individuals.

\section{References}

Ahmad, R. A. R., Tower, G., Plummer, J., \& Aripin, N. (2010). Transparency and clarity of Water accounting reporting. Journal of the Asia-Pacific Center for Environmental Accountability, 16(4), 4-19.

Ahmed, et al. (2006). Ensuring safe drinking water in Bangladesh. Science, 314, 1687-1688. https://doi.org/10.1126/science.1133146

Ahsan, et al. (2006). Arsenic exposure from drinking water and risk of premalignant skin lesions in Bangladesh: Baseline results from the health effects of arsenic longitudinal study. American Journal of Epidemiology, 163(12), 1138-1148. https://doi.org/10.1093/aje/kwj154

Alonso, A. D. (2010). How green are small wineries: Western Australia's case. British Food Journal, 112(2), 155-170. https://doi.org/10.1108/00070701011018842

Amini, et al. (2008). Statistical modeling of global geogenic fluoride contamination in groundwaters. Environmental Science \& Technology, 42(10), 3662-3668. https://doi.org/10.1021/es071958y

Asian Development Bank (2013). Thinking about water differently: managing the Water-food-energy nexus. Manila, Asian Development Bank.

Bundschuh, et al. (2004). Groundwater arsenic in the Chaco-Pampean Plain, Argentina: Case study from Robles county, Santiago del Estero Province. Applied Geochemistry, 19, 231-243. https://doi.org/10.1016/j.apgeochem.2003.09.009

Buschmann, J., Berg, M., Stengel, C., \& Sampson, M. L. (2007). Arsenic and manganese Contamination of drinking water resources in Cambodia: Coincidence of risk areas with low relief topography. Environmental Science \& Technology, 41(7), 2146-2152. https://doi.org/10.1021/es062056k

Central Bank of Nigeria (CBN) Statistical Bulletin, 2017.

Chakraborti, D., et al. (2004). Groundwater arsenic contamination and its health effects in the Ganga-Meghna Brahmaputra plain. Journal of Environmental Monitoring, 6, 74N-83N.

Chen, Y., \& Ahsan, H. (2004). Cancer burden from arsenic in drinking water in Bangladesh. American Journal of Public Health, 94(5), 741-744. https://doi.org/10.2105/AJPH.94.5.741

Chen, et al. (2007). Reduction in urinary arsenic levels in response to arsenic mitigation efforts in Araihazar, Bangladesh. Environ Health Perspect, 115(6), 817-923. https://doi.org/10.1289/ehp.9833

Chenhall, R. H. (2003). Management control systems design within its organizational context: Findings from contingency-based research and directions for the future. Accounting, Organizations and Society, 28(2-3), 127-168. https://doi.org/10.1016/S0361-3682(01)00027-7

Daniel, M. A., \& Sojamo, S. (2012). From risks to shared value? Corporate strategies in Building a global water accounting and disclosure regime. Water Alternatives, 5(3), 636-657.

Egan, M. (2012). Water management and accounting change: a study of food and beverage Producing organizations. A $\mathrm{PhD}$ Thesis submitted to Discipline of Accounting, The University of Sydney Business School.

Flemming, M., Berit, H., Marianne, Z., Louise, M., \& Pedersen, O. G. (2015). Water resource Accounts and accounts for the quantity and value of ecosystem services connected with The Danish Water Resources methods and requirements. Danish Centre for Environment and Energy (DCE) No. 116.

Food and Agriculture Organization (FAO, 2012). Coping with water scarcity: an action Framework for agriculture and food security. FAO Water Reports 38. Available at: www.fao.org.

Gleick, P. H. (1998). Water in Crisis: paths to sustainable water use. Ecological Applications, 8(3), 571-579. https://doi.org/10.1890/1051-0761(1998)008[0571:WICPTS]2.0.CO;2

Goesch, T., Hone, S., \& Gooday, P. (2007). Groundwater management: issues affecting the Efficient allocation of groundwater. Australian Commodities, 14(1), 201-211.

Green, et al. (2015). Freshwater ecosystem services supporting humans: pivoting from water crisis to water solutions. Global Environmental Change, 34, 108-118. https://doi.org/10.1016/j.gloenvcha.2015.06.007

Herberger, M. (2012). Australia's millennium drought: impacts and responses' in PH Gleick (Ed.). The World's Water Volume 7: The Biennial Report on Freshwater Resources, Island Press, Washington DC, 97-125.

Hughes, M. F., Beck, B. D., Chen, Y., Lewis, A. S., \& Thomas, D. J. (2011). Arsenic exposure and Toxicology: A historical 
perspective. Toxicological Sciences, 132(2), 305-332. https://doi.org/10.1093/toxsci/kfr184

Inauen, J. (2012). Theory-based promotion of safe water consumption. $\mathrm{PhD}$ Thesis presented To the Faculty of Arts of the University of Zurich.

Johnston, R. B., \& Sarker, M. H. (2007). Arsenic mitigation in Bangladesh: National screening Data and case studies in three upazilas. Journal of Environmental Science and Health, Part A: Toxic/hazardous substances and Engineering, 42(12), 1889-1896.

Katherine, L. C. (2015). Environmental management accounting as a medium for improved Water management in the Australian Wine Industry: An Empirical Analysis. Ph.D Dissertation submitted to the School of Commerce, University of South Australia Business School, University of South Australia.

Malmi, T., \& Granlund, M. (2009). In search of management accounting theory. European Accounting Review, 18(3), 597-620. https://doi.org/10.1080/09638180902863779

Mosse, K. P. M., Patti, A. F., Christen, E. W., \& Cavagnaro, T. R. (2011). Review: Winery Wastewater quality and treatment options in Australia. Australian Journal of Grape and Wine Research, 7(2), 111-122. https://doi.org/10.1111/j.1755-0238.2011.00132.x

Otley, D. T. (1980). The contingency theory of management accounting: achievement and Prognosis. Accounting, Organizations and Society, 5(4), 413-428. https://doi.org/10.1016/0361-3682(80)90040-9

Rogers, R. W. (1975). A protection motivation theory of fear appeals and attitude change. The Journal of Psychology, 91(1), 93-114. https://doi.org/10.1080/00223980.1975.9915803

Rogers, R. W. (1983). Cognitive and psychological processes in fear appeals and attitude Change: A revised theory of protection motivation. In J. T. Cacioppo \& R. E. Petty (Eds.), Social Psychophysiology (pp. 153176). New York: Guildford Press.

Schmidt, G., Bassi, N., \& Benitez, S. C. (2017). Blueprint for national water accounting Framework in India. Background Report. Australia, Fresh Thoughts Consulting GMBH.

Shaw, W. D., Walker, M., \& Benson, M. (2005). Treating and drinking well water in the Presence of health risks from arsenic contamination: Results from a U.S. hot spot. Risk Analysis, 25(6), 1531-1543. https://doi.org/10.1111/j.1539-6924.2005.00698.x

Smedley, P. L., Kinniburgh, D. G. (2002). A review of the source, behaviour and distribution of Arsenic in natural waters. Applied Geochemistry, 17, 517-568. https://doi.org/10.1016/S0883-2927(02)00018-5

Tisdell, J. G. (2001). The environmental impact of water markets: An Australian case-study. Journal of Environmental Management, 62, 113-120. https://doi.org/10.1006/jema.2001.0423

United Nations (2017). The Sustainable Development Goals Report 2017. New York, United Nations.

Wasserman, et al. (2004). Water arsenic exposure and children's intellectual function in Araihazar, Bangladesh. Environmental Health Perspectives, 112(13), 1329-1333. https://doi.org/10.1289/ehp.6964

Water Accounting Standards Board (2009). Water accounting conceptual framework for the Preparation and presentation of general purpose water accounting reports. Commonwealth of Australia, Canberra. Retrieved from: www.bom.gov.au/water/wasb on September 10, 2018.

Winpenny, J. (2012). Green accounting and data improvement for water resources. United Nations World Water Assessment Programme. WWDR, 4.

World Water Council (WWC, 2018). Water accounting for water governance and sustainable Development. Food and Agriculture Organization of the United Nations. Available at: www.worldwatercouncil.org.

World Water Development Report (WWDR, 2016). Water and Forum. WWDR, Canberra Australia.

Yang, Y., Yang, L., Cao, S., \& Cheng, Y. (2017). A method of evaluating water resource assets and liabilities: A case study of Jinan City, Shandong Province. MDPI Water Journal, 9(575), 1-16. https://doi.org/10.3390/w9080575

\section{Copyrights}

Copyright for this article is retained by the author(s), with first publication rights granted to the journal.

This is an open-access article distributed under the terms and conditions of the Creative Commons Attribution license which permits unrestricted use, distribution, and reproduction in any medium, provided the original work is properly cited. 